\title{
Morphological Analysis of Vermilion Border and its Forensic Applications
}

\author{
Bindal U. ${ }^{1, *}$, Shajan K. ${ }^{1}$, Mitra NK. ${ }^{1}$, Priydarshni B. ${ }^{2}$ \\ ${ }^{1}$ Taylor's University, Lakeside campus, Malaysia \\ ${ }^{2}$ School of Dentistry, University Malaya, Malaysia
}

Copyright (C) 2015 Horizon Research Publishing All rights reserved.

\begin{abstract}
Introduction: Lips are two fleshy folds surrounding the oral orifice. Grooves in the zone of transition of the human lips were named as "sulci labiorum rubrorum". Study of lip prints is called as "cheiloscopy". The morphological patterns of the two fleshy folds vary grossly in both sexes. Aim: The study was aimed to find the most common patterns, sexual variations, anthropometric measurements and the morphology of lips. Material and Methods: The present study was conducted on 300 subjects in the age group between 18- 65 years. The impressions of the vermellion border were obtained. Morphometric analysis of the obtained impressions was done by using scale. The height, width of the mouth was measured. The wrinkles and grooves on the impressions obtained were studied with help of a magnifying lens using Suzuki's classification. The prints of an individual subject were repeated each year for seven years. Results and discussion: The range in the width of mouth varied from $35-75 \mathrm{~mm}$. The observed widths in males and females subjects varied. The male lips were wider compared to the females. In all age groups studied, in the maximum number of subjects (male and females), the height was ranging between $16-20 \mathrm{~mm}$. the morphometric description of labial folds recognizes, the lips as thin, medium, thick and puffy. The present study on the subjects was medium variety in both sexes i.e. $40 \%$ each. The analysis of wrinkles and grooves on the impressions reveals that no impression matches with each other. There was no change observed in the impression of the study subject after seven years. Conclusion: The measurements of width of mouth, height of upper and lower lips and total lip height was greater in males as compared to females. It was concluded that males have a larger mouth and bigger lips than female. The medium types of lips were common in both sexes. There was no change in the lip prints patterns and the anthropometric measurements during seven years of duration. The knowledge of the patterns and measurements can be used as an instrument to identify subject under in the court of law.
\end{abstract}

$\begin{array}{lcr}\text { Keywords } & \text { Vermilion Border, Labial, Suzuki’s } \\ \text { Classification, } & \text { Anthropometric } & \text { Measurements, }\end{array}$

Morphological Types

\section{Introduction}

Lips are two fleshy folds surrounding the oral orifice. They are lined externally by skin and internally by mucosa. The skin is continuous with the mucosa at the transitional or Vermilion border, a reddish zone covered by the thin keratinized epithelium. Line of contact between lips (oral fissure) lies just above the cutting edges of the superior incisor teeth and on each side a labial commissure forms the angle of mouth, usually near the first premolar tooth. Externally, in the upper lip centrally situated is a shallow vertical groove, the philtrum, ends below in a slight tubercle and limited by lateral ridges. Internally each lip is connected to the gum by a median labial frenulum that of the upper lip being larger (1).

There are three anatomical zones recognized on the lips; outer skin, vermilion area and inner mucosal surface. The external skin is similar to the skin on the body. It has hair follicles, quite thicker in males, sebaceous glands and sweat glands. The underlying skeletal muscles are striated. The vermilion area which connects the outer skin to the inner mucosal surface is also called as the transitional zone. Only humans have a vermilion area but in animals the transition is much sharper. The corners of the mouth or labial commissures are junctions between the vermilion area of the upper and lower lips. Epithelium of the vermilion area exhibits a less well developed stratum corneum than skin. It does not have stratum lucidium. (2)

The labial mucosa and a part of the oral mucosa are not smooth like the buccal mucosa and soft palate. It has many elevations and depressions forming a characteristic pattern called lip prints, examination of which is referred to as cheiloscopy. (3). The lips exhibit sexual dimorphism. (4)

The lips are diverse in terms of dryness. In reverse to their surface pattern the dimensions of the lips changes significantly with age. The phase in which the vertical wrinkles appear advocated a possible influence of hormones. 
The dryness of lips is statistically marked in aged women. The upper lip is reportedly more hydrated than the lower one. The vertical wrinkles of lips are linearly related to age in both number and visibility (5).

The establishment of the identity in the court of law is challenging. Many parameters have been recognized in and around the oral cavity. The impressions of these structures were used as an evidence to help in the process of establishment of identity. The lip prints found on drinking glasses, facial tissues, undergarments and pornographic magazines could be used as evidence in the court of law to link or exclude a suspect (6). The identification of latent print evidence is often considered the key in solving a crime and they should always be considered when processing a crime scene, even if there are no traces of lipstick (7).

The study aims to analyse the morphological patterns, shape and dimensions of vermilion area prevailing in the population of north India and investigate the differences of morphological patterns in both sexes.

\section{Materials and Methods}

The study was conducted on 300 subjects consisting up of equal number of male and female North Indian individuals in the age group between 18- 65 years. The labial impressions were collected in the month of April and May in the year 2005. The temperature ranges from 25-300 $\mathrm{C}$ during these months. The labial impressions of a selected group of 20 subjects age group between 18-30years from the 300 study sample were repeated after one year and each year until seven years. A 4"x10" strip of thin bond paper was fixed on the cardboard of same size with the help of the clips. The lipstick was applied with a single motion evenly on the lips. The subject was asked to rub his/ her lips together to spread the lipstick evenly. During the application of the lipstick the subject was asked to sit erect and with the mouth closed and lips slightly opened such that the lips appeared relaxed and puckered. The cardboard bearing the bond paper was then pressed to the subject's lips] with the central portion of the lips dabbed first and then pressed uniformly up to the left and right corners of the lips. Care was taken to avoid sliding of the lips so as to prevent smudging of the print over the entire area of the red part of the lips. Three impressions were taken on the same strip of paper side by side by applying the same amount of pressure and without further any addition of lipstick. 'The first two impressions of the lips were taken by the method described above. The second impression was slightly lighter than the first and the third impression was taken by folding the strip of paper and then pressed between the two lips so as to cover the entire red portion of the lips. After obtaining the print they were assigned the respective name, age and sex. Each lip print was carefully examined three times to avoid misreading the prints. These prints were carefully studied with help of a magnifying lens using Suzuki's classification (8). Follows:

Table 1. Suzuki's classification

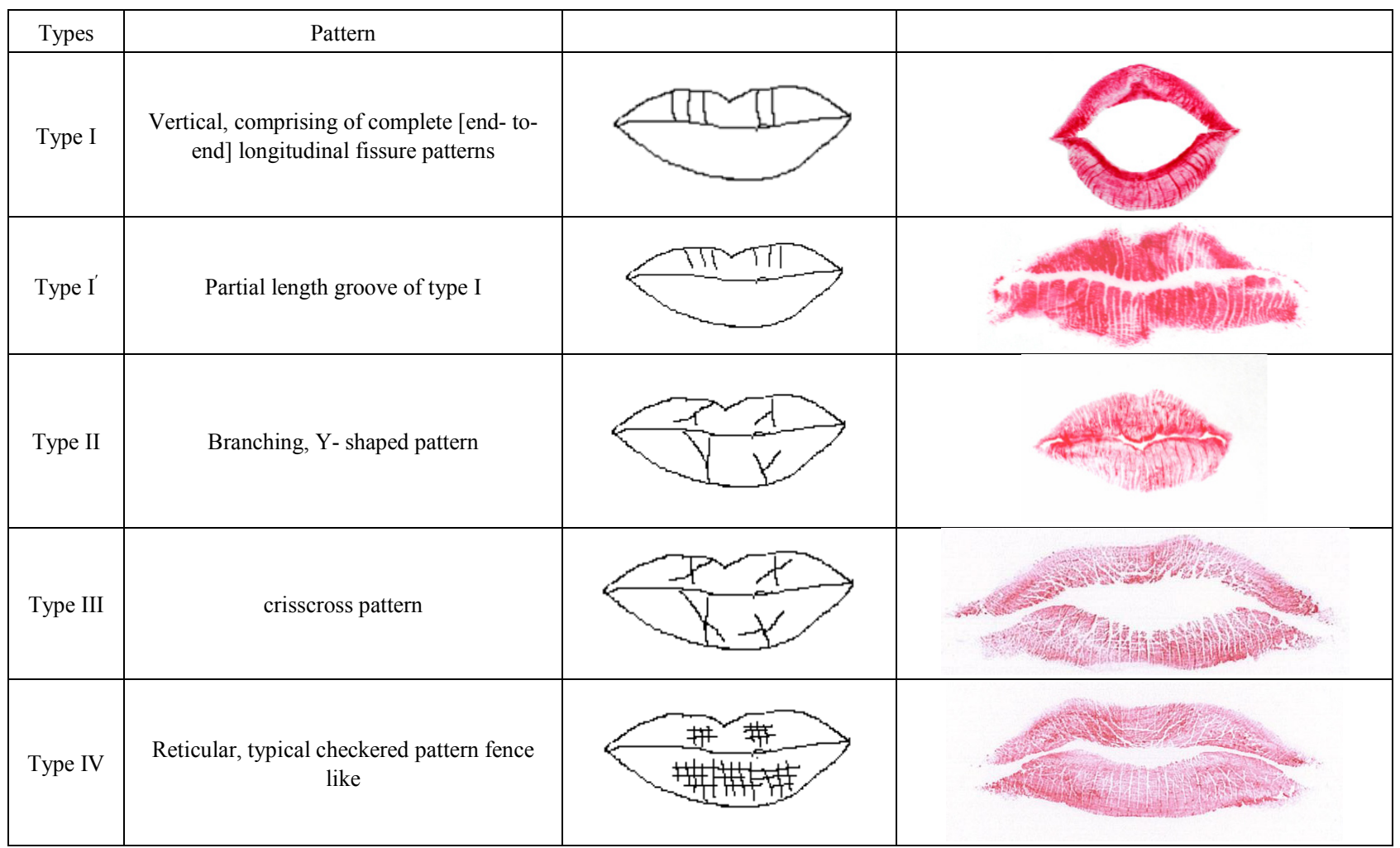


Morphological classification as proposed by Indra and Bhasin (9) and anthropometric measurements of lips were also recorded. For the purpose of the measurement simple ruler scale was used and the measurements of the prints and of the subject were taken. Care was taken that the lips were relaxed and were in normal shape and size. Each measurement was repeated three times to avoid any errors.

Following were the anthropometric measurements taken:-

i) Form- thin/ medium/ thick/ puffy.

Table 2. Morphological classification as proposed by Indra and Bhasin

\begin{tabular}{|c|c|}
\hline Form & 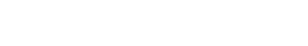 \\
\hline \multicolumn{2}{|l|}{ Thin } \\
\hline \multicolumn{2}{|c|}{ Medium } \\
\hline \multicolumn{2}{|l|}{ Thick } \\
\hline Puffy & \\
\hline
\end{tabular}

ii) Height of upper membranous lip- from tubercle of philtrum to midpoint of oral fissure (in $\mathrm{mm}$ ).

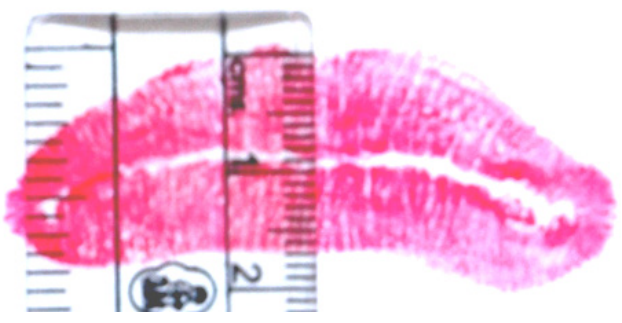

Figure 1.

iii) Height of lower membranous lip- from the center of vermilion border of lip to the midpoint of oral fissure (in $\mathrm{mm}$ ).

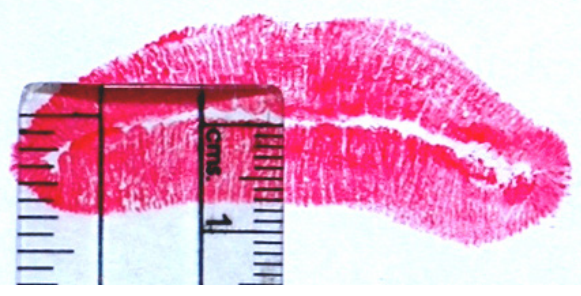

Figure 2. iv) Width of lips- the shortest distance between the tips of angles of mouth when mouth is gently closed (in $\mathrm{mm}$ ).

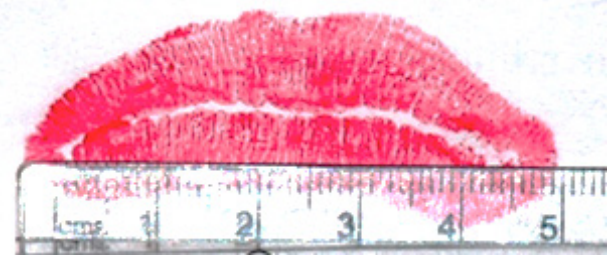

Figure 3.

\section{Results}

Table 3 . Distribution of Morphological Types of lips in age group 18-65 years

\begin{tabular}{|c|c|c|c|c|}
\hline \multirow{2}{*}{ Types } & \multicolumn{2}{|c|}{ MALE } & \multicolumn{2}{c|}{ FEMALE } \\
\cline { 2 - 5 } & $\mathrm{n}=150$ & $\begin{array}{c}\text { Percentage } \\
\%\end{array}$ & $\mathrm{n}=150$ & $\begin{array}{c}\text { Percentage } \\
\%\end{array}$ \\
\hline Thin & 36 & 24.00 & 55 & 36.67 \\
\hline Medium & 60 & 40.00 & 60 & 40.00 \\
\hline Thick & 44 & 29.34 & 32 & 21.33 \\
\hline Puffy & 10 & 06.66 & 03 & 02.00 \\
\hline
\end{tabular}

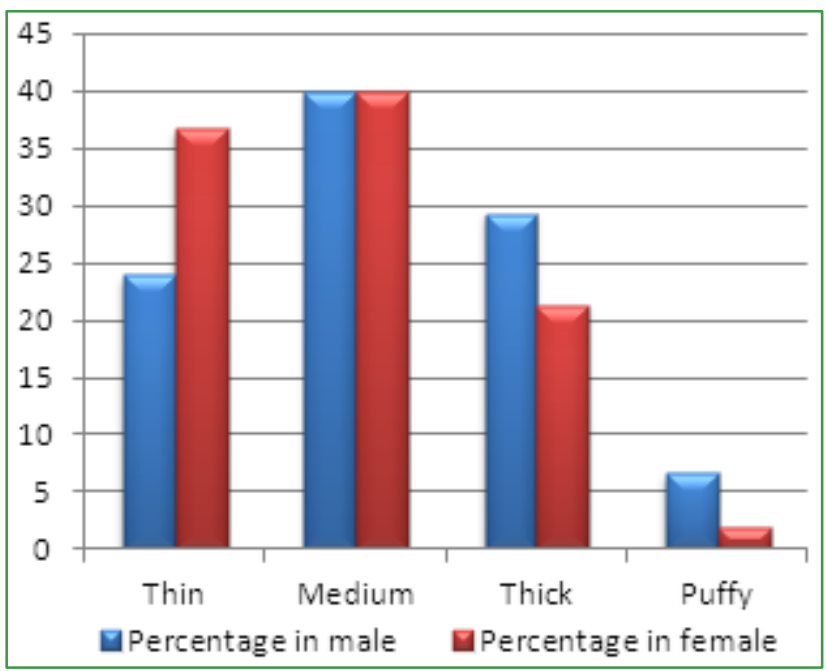

Figure 4. Distribution of Morphological Types of lips in age group 18-65 years

The most common type of lips noted were of medium verity in both sexes i.e. $40 \%$ each.

Total height of Lip: The range in the total height of lips varied from $10-30 \mathrm{~mm}$. The same was categorized into four groups with a class interval of five. The following table shows the distribution in both sexes. 
Table 4. Percentage Distribution of Cases with Various Ranges of Total Height of Lips in Different Age Groups

\begin{tabular}{|c|c|c|c|c|c|c|c|c|}
\hline \multirow{2}{*}{$\begin{array}{c}\text { Total Height of } \\
\text { both lips (mm) }\end{array}$} & \multicolumn{4}{|c|}{ Age } & \multicolumn{4}{c|}{$\begin{array}{c}\text { Age } \\
\text { 31- 65 Yrs }\end{array}$} \\
\cline { 2 - 11 } & \multicolumn{2}{|c|}{ MALE } & \multicolumn{2}{|c|}{ FEMALE } & \multicolumn{2}{c|}{ MALE } & \multicolumn{2}{c|}{ FEMALE } \\
\cline { 2 - 11 } & $\mathrm{n}=125$ & $\begin{array}{c}\text { Percentage } \\
(\%)\end{array}$ & $\mathrm{n}=125$ & $\begin{array}{c}\text { Percentage } \\
(\%)\end{array}$ & $\mathrm{n}=25$ & $\begin{array}{c}\text { Percentage } \\
(\%)\end{array}$ & $\begin{array}{c}\mathrm{n}=25 \\
\text { Percentage } \\
(\%)\end{array}$ \\
\hline $10-15$ & 13 & 10.4 & 41 & 32.8 & 03 & 12.0 & 06 & 24 \\
\hline $16-20$ & 68 & 54.4 & 69 & 55.2 & 15 & 60.0 & 17 & 68 \\
\hline $21-25$ & 33 & 26.4 & 15 & 12.0 & 07 & 28.0 & 02 & 08 \\
\hline $26-30$ & 11 & 08.8 & 00 & 00.0 & 00 & 00.0 & 00 & 00 \\
\hline
\end{tabular}

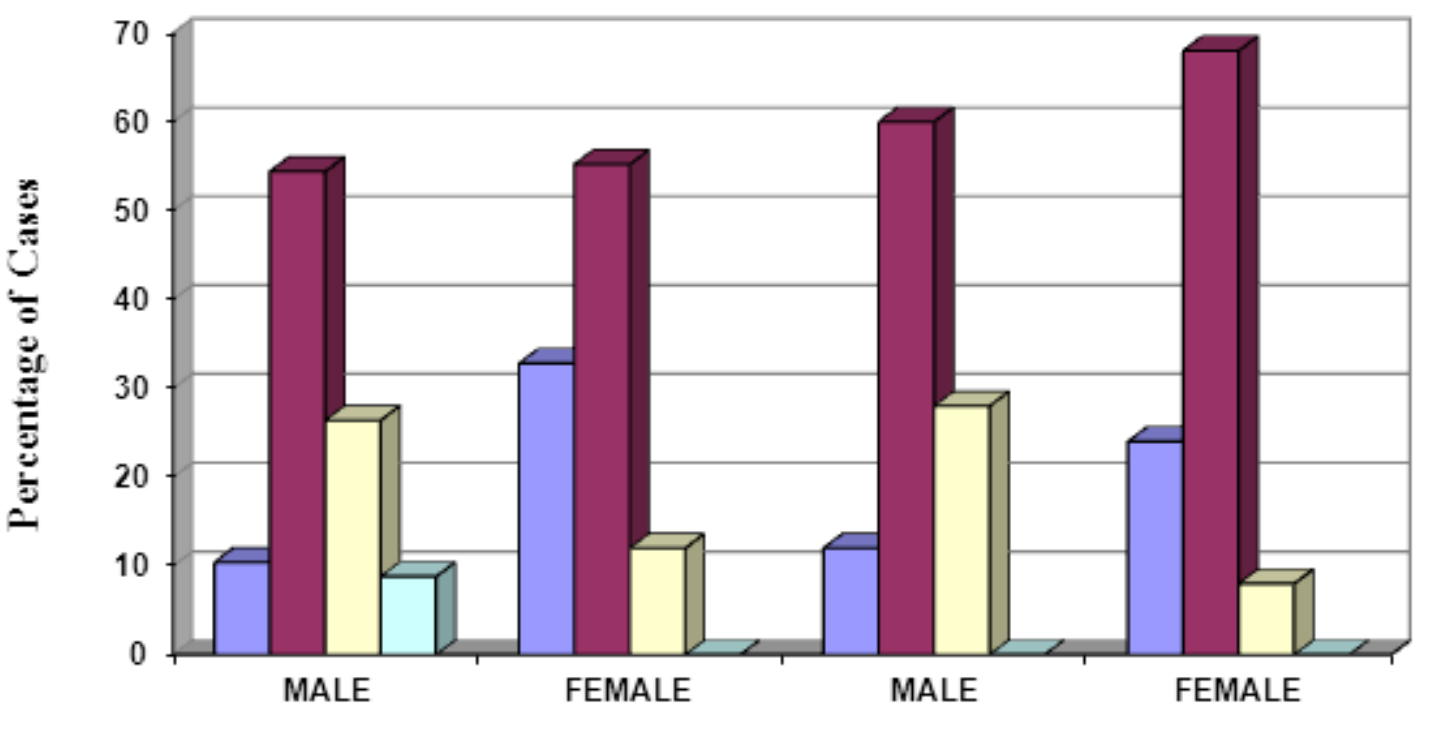

Agel8-30 Yrs

Age 31-65 Yrs

\section{口10 TO $15 \quad \square 16$ TO $20 \quad \square 21$ TO $25 \quad \square 26$ TO 30}

Figure 5. Percentage Distribution of Cases with Various Ranges of Total Height of Lips in Different Age Groups

In all age groups studied, in the maximum number of subjects (male and females), the height was ranging between 16- 20 $\mathrm{mm}$.

Width of Mouth The range in the width of mouth varied from $35-75 \mathrm{~mm}$. The same was categorized into eight groups with a class interval of five. The following table shows the distribution in both sexes.

Table 5. Measurement of the Width of Mouth in Age Groups of Both Sexes

\begin{tabular}{|c|c|c|c|c|c|c|c|c|}
\hline \multirow{2}{*}{$\begin{array}{c}\text { Width } \\
(\mathrm{mm})\end{array}$} & \multicolumn{4}{|c|}{ Age 18-30 Yrs } & \multicolumn{4}{c|}{ Age 31-65 Yrs } \\
\cline { 2 - 10 } & \multicolumn{2}{|c|}{ MALE } & \multicolumn{2}{c|}{ FEMALE } & \multicolumn{2}{c|}{ MALE } & \multicolumn{3}{c|}{ FEMALE } \\
\hline & $\mathrm{n}=125$ & $\begin{array}{c}\text { Percentage } \\
(\%)\end{array}$ & $\mathrm{n}=125$ & $\begin{array}{c}\text { Percentage } \\
(\%)\end{array}$ & $\mathrm{n}=25$ & $\begin{array}{c}\text { Percentage } \\
(\%)\end{array}$ & $\begin{array}{c}\mathrm{n}=25 \\
\text { Percentage } \\
(\%)\end{array}$ \\
\hline $35-40$ & 00 & 00.0 & 02 & 01.6 & 0 & 00.0 & 0 & 00.0 \\
\hline $41-45$ & 05 & 04.0 & 04 & 03.2 & 0 & 00.0 & 0 & 00.0 \\
\hline $46-50$ & 07 & 05.6 & 16 & 12.8 & 4 & 16.0 & 3 & 12.0 \\
\hline $51-55$ & 32 & 25.6 & 51 & 40.8 & 8 & 32.0 & 9 & 36.0 \\
\hline $56-60$ & 39 & 31.2 & 42 & 33.6 & 8 & 32.0 & 6 & 24.0 \\
\hline $61-65$ & 33 & 26.4 & 10 & 08.0 & 4 & 16.0 & 6 & 24.0 \\
\hline $66-70$ & 07 & 05.6 & 00 & 00.0 & 0 & 00.0 & 1 & 04.0 \\
\hline $71-75$ & 02 & 01.6 & 00 & 00.0 & 1 & 04.0 & 0 & 0 \\
\hline
\end{tabular}




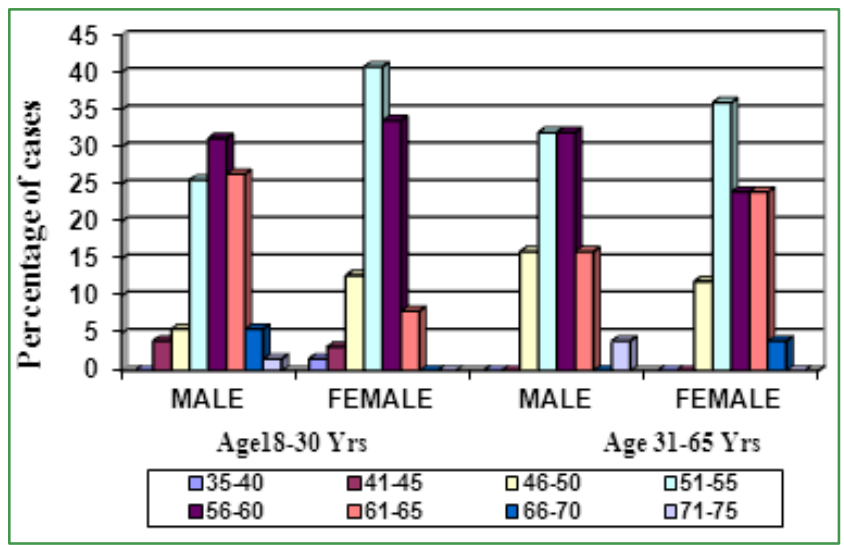

Figure 6. Percentage Distribution of Cases with Various Ranges of Mouth Width in Different Age Groups

Among different age groups of both sexes $31.2 \%$ of the male subjects in the age group 18- 31 years were having a maximum mouth width between $56-60 \mathrm{~mm}$ while $32 \%$ of the male subjects in age group between 31- 65 years were having width of mouth between $51-55 \mathrm{~mm}$ and $56-60 \mathrm{~mm}$.

The maximum number of females had a mouth width of $51-55 \mathrm{~mm}$ in both age groups i.e. $40.8 \%$ and $36 \%$ separately.

In the males of age group 18- 30 years, the mean width was $57.73 \pm 6.08 \mathrm{~mm}$, height of upper lip was $9.4 \pm 2.04 \mathrm{~mm}$ and that of lower lip was $10.52 \pm 2.05 \mathrm{~mm}$. Total height of the upper lip and the lower lip was $19.92 \pm 3.63 \mathrm{~mm}$. In the males between the age group 31- 65years mean width was $56 \pm 6.46 \mathrm{~mm}$, height of the upper lip was $9.0 \pm 1.47 \mathrm{~mm}$ and of the lower lip was $9.84 \pm 1.59 \mathrm{~mm}$. Total heights of the upper lip and the lower lip was $18.84 \pm 2.68 \mathrm{~mm}$.
In the females between age group 18- 30 years mean width was $54.4 \pm 4.78 \mathrm{~mm}$, height of the upper lip was $8.06 \pm 1.65$ $\mathrm{mm}$ and that of the lower lip was $8.75 \pm 1.73 \mathrm{~mm}$. The total height of the upper lip and that of the lower lip was 16.81土 $3.001 \mathrm{~mm}$. In the females between age group 31- 65years the mean width was $56.52 \pm 5.33$, height of the upper lip was $8.08 \pm 1.46 \mathrm{~mm}$ and that of the lower lip was $9.4 \pm 1.58 \mathrm{~mm}$. Total heights of the upper lip and of the lower lip was $17.48 \pm$ $2.8005 \mathrm{~mm}$.

In males irrespective of age the mean width of mouth, height of upper and lower lip and total height was 57.44 \pm $6.16,9.33 \pm 1.96$, and $10.40 \pm 1.99,19.74 \pm 3.51 \mathrm{~mm}$ respectively. In females irrespective of age the mean width of mouth, height of upper and lower lip and total height were $54.75 \pm 4.93,8.06 \pm 1.62$ and $8.86 \pm 1.70,16.92 \pm 2.96 \mathrm{~mm}$ respectively.

In all the subjects irrespective of age and sex the mean width of mouth, height of upper and lower lip and total height were $56.1 \pm 5.73,8.7 \pm 1.90$ and $9.6 \pm 2.04,18.33 \pm 3.53$ $\mathrm{mm}$ respectively. Any two quadrants having similar types of patterns were most common (77.33\%) in all the subjects. The incidence is more in females $(80.66 \%)$ as compared to males $(73.99 \%)$. Any three quadrants having similar patterns were least commonly observed (4\%). All quadrants having similar patterns were more commonly observed in females $(10 \%)$ than in males $(2.67 \%)$. The category of having all dissimilar quadrants was more commonly observed in males $(27.33 \%)$ than in females $(5.33 \%)$.

In the group of 20 selected subjects following are the results obtained:

Table 6. Lip Print Patterns in Various Quadrants, Anthropometric Measurements and Morphological Types of Lips in Males of Age Group 18-30 Years at the beginning of the study

\begin{tabular}{|c|c|c|c|c|c|c|c|c|c|c|c|}
\hline S NO & Age & Sex & ULQ 1 & ULQ 2 & LLQ 3 & LLQ 4 & WIDTH & UL & LL & TH F L & MT F LS \\
\hline 1 & 22 & M & I II & II I & II I I' & I' I II & 61 & 11 & 14 & 25 & THIN \\
\hline 2 & 24 & M & I' II & I' II & I' II & I' II & 60 & 11 & 15 & 26 & THIN \\
\hline 3 & 26 & M & I' II & II I' & II I' I & I I' II & 45 & 10 & 9 & 19 & MEDIUM \\
\hline 4 & 24 & M & II I & I II & II I' I & I I' II & 65 & 10 & 8 & 18 & MEDIUM \\
\hline 5 & 23 & M & I' I II & II I II & II I IV & IV I II & 56 & 7 & 12 & 19 & MEDIUM \\
\hline 6 & 21 & M & II IV & IV II & I' II & II I' & 59 & 6 & 8 & 14 & PUFFY \\
\hline 7 & 23 & M & I' I II & II I & I' I & I I' & 57 & 9 & 10 & 19 & MEDIUM \\
\hline 8 & 24 & M & II I & I II & I III II & I III II & 53 & 8 & 10 & 18 & MEDIUM \\
\hline 9 & 25 & M & II I I' IV & IV I' I II & II I' IV & IV I' II & 46 & 9 & 11 & 20 & MEDIUM \\
\hline 10 & 23 & M & II IV & IV II & II I' IV & II I' IV & 63 & 9 & 11 & 20 & MEDIUM \\
\hline
\end{tabular}

Table 7. Lip Print Patterns in Various Quadrants, Anthropometric Measurements and Morphological Types of Lips in Females of Age Group 18-30 Years at the beginning of the study

\begin{tabular}{|c|c|c|c|c|c|c|c|c|c|c|c|}
\hline S NO & Age & Sex & ULQ 1 & ULQ 2 & LLQ 3 & LLQ 4 & WIDTH & UL & LL & TH F L & MT F LS \\
\hline 1 & 20 & F & I I' II & II I' I & I' II I & I II I' & 62 & 9 & 10 & 19 & MEDIUM \\
\hline 2 & 22 & F & IV & IV I II I & I' II I & I II I' & 52 & 9 & 7 & 16 & MEDIUM \\
\hline 3 & 24 & F & I' II IV & IV II I & I I' II & II I' I & 56 & 7 & 10 & 17 & MEDIUM \\
\hline 4 & 21 & F & III I' IV I & I' IV III & III I' I & I I' III & 52 & 9 & 10 & 19 & MEDIUM \\
\hline 5 & 22 & F & I' I II & II I' I & II I I' & I' I II & 55 & 11 & 11 & 22 & THICK \\
\hline 6 & 25 & F & II I' I & I I' II & II III IV & IV III & 59 & 8 & 10 & 18 & MEDIUM \\
\hline 7 & 24 & F & III I IV & IV I II & II I' I & I I' II & 49 & 9 & 9 & 18 & MEDIUM \\
\hline 8 & 30 & F & II I IV & IV I II & I IV & IV II & 59 & 6 & 8 & 14 & MEDIUM \\
\hline 9 & 25 & F & I I' II & II I' I & I' I & I I' & 58 & 11 & 11 & 22 & THICK \\
\hline 10 & 26 & F & II I III & III I II & II I & I II I' & 52 & 7 & 9 & 16 & MEDIUM \\
\hline
\end{tabular}


The results observed after every year until seven years were not different as they were observed at the commencement of the study.
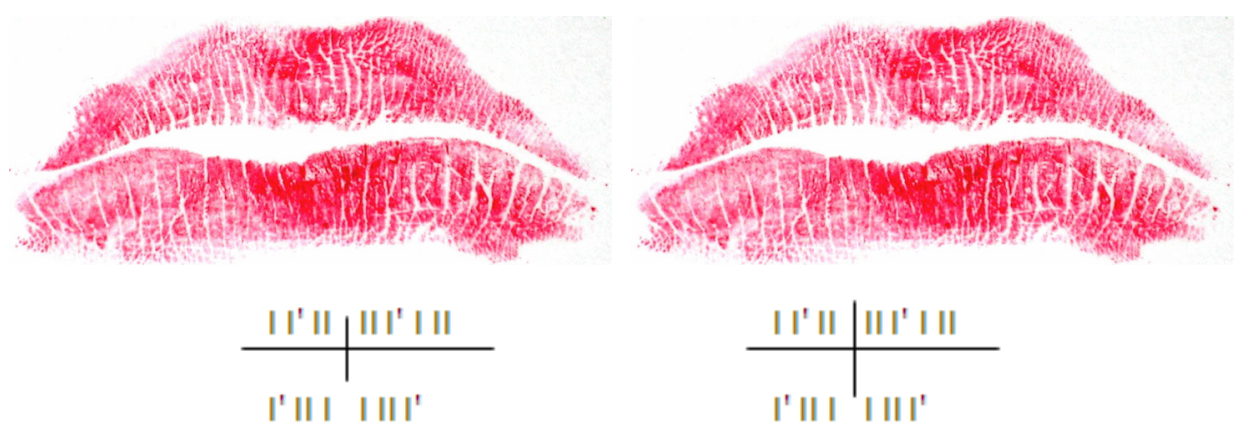

Figure 7. Lip prints of a female subject aged 19 years (18- 30 years groups) displaying no change in the pattern of lip prints on evaluation after one year.
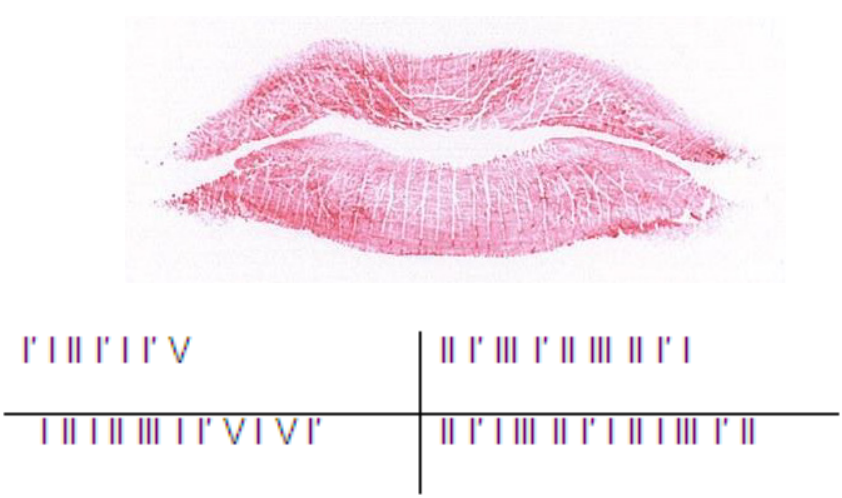

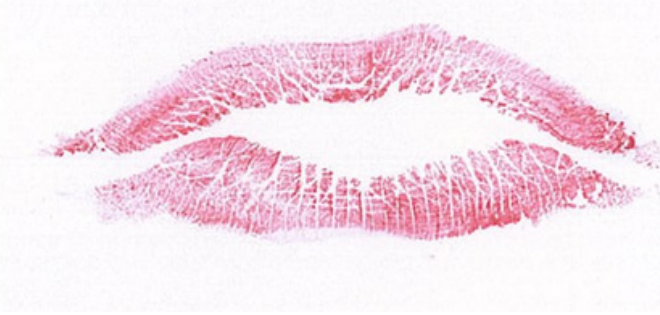

\begin{tabular}{|c|c|}
\hline I'। II I' I I' V & | || I' ||| I' || ||| || I' | \\
\hline||$\|||||||||^{\prime} \vee V \mid V I^{\prime}$ & $\left|\| I^{\prime}\right|||||||\left|I^{\prime}\right|||||||||\left|I^{\prime}\right| \mid$ \\
\hline
\end{tabular}

Figure 8. Lip prints of a female subject aged 28 years (18-30 years groups) displaying no change in the pattern of lip prints on evaluation after seven years.

Table 8. Comparison of Anthropometric Studies of the Mouth

\begin{tabular}{|c|c|c|c|c|c|c|c|c|c|c|c|c|}
\hline \multirow{2}{*}{$\begin{array}{l}\text { Measurements } \\
\text { of Lips }(\mathrm{mm})\end{array}$} & \multicolumn{2}{|c|}{$\begin{array}{l}\text { Wilkinson et al } \\
\qquad \mathrm{n}=95\end{array}$} & \multicolumn{2}{|c|}{$\begin{array}{c}\text { Farkas et al } \\
n=309\end{array}$} & \multicolumn{2}{|c|}{$\begin{array}{l}\text { Ferrario et al } \\
\quad \mathrm{n}=108\end{array}$} & \multicolumn{2}{|c|}{$\begin{array}{l}\text { Nanda et al } \\
\mathrm{n}=2575\end{array}$} & \multicolumn{4}{|c|}{$\begin{array}{c}\text { Present Study } \\
n=300\end{array}$} \\
\hline & $\begin{array}{c}\text { Male } \\
(\mathrm{n}=49)\end{array}$ & $\begin{array}{c}\text { Female } \\
(\mathrm{n}=46)\end{array}$ & $\begin{array}{c}\text { Male } \\
(\mathrm{n}=109)\end{array}$ & $\begin{array}{l}\text { Female } \\
(\mathrm{n}=200)\end{array}$ & $\begin{array}{c}\text { Male } \\
(\mathrm{n}=57)\end{array}$ & $\begin{array}{l}\text { Female } \\
(\mathrm{n}=51)\end{array}$ & $\begin{array}{c}\text { Male } \\
(\mathrm{n}=2525)\end{array}$ & $\begin{array}{l}\text { Female } \\
(\mathrm{n}=50)\end{array}$ & $\begin{array}{c}\text { Male } \\
(\mathrm{n}=\mathrm{i} 25)\end{array}$ & $\begin{array}{l}\text { Female } \\
(\mathrm{n}=125)\end{array}$ & $\begin{array}{c}\text { Male } \\
(\mathrm{n}=25)\end{array}$ & $\begin{array}{l}\text { Female } \\
(\mathrm{n}=25)\end{array}$ \\
\hline Mouth Width & 50.3 & 47.9 & 54.5 & 50.2 & 50.4 & 47.4 & 50.4 & 47.0 & 57.73 & 54.4 & 56 & 56.52 \\
\hline $\begin{array}{l}\text { Height of } \\
\text { Upper Lip }\end{array}$ & 6.1 & 62.2 & 08.0 & 08.7 & & & & & 09.40 & 08.06 & 09.00 & 08.08 \\
\hline $\begin{array}{l}\text { Height of } \\
\text { Lower Lip }\end{array}$ & 9.4 & 08.5 & 09.3 & 09.4 & & & & & 10.52 & 08.75 & 09.84 & 09.40 \\
\hline $\begin{array}{c}\text { Total Height } \\
\text { of Lips }\end{array}$ & 15.5 & 14.7 & 17.3 & 18.1 & 17.9 & 17.7 & & & 19.92 & 16.81 & 18.84 & 17.48 \\
\hline
\end{tabular}

Table 9. Comparison of Present Study with Wilkinson et al

\begin{tabular}{|c|c|c|c|}
\hline \multirow{2}{*}{$\begin{array}{c}\text { Measurements } \\
\text { of Lips (mm) }\end{array}$} & \multicolumn{2}{|c|}{$\begin{array}{c}\text { Wilkinson et al } \\
\text { n=95 }\end{array}$} & Ind $(\mathrm{n}=15)$ \\
\cline { 2 - 4 } & WE $(\mathrm{n}=80)$ & 07.8 & North Indians \\
\hline Height of Upper Lip & 05.8 & 10.5 & 08.70 \\
\hline Height of Lower Lip & 08.7 & 18.3 & 09.60 \\
\hline Total Height of Lips & 14.5 & & 18.33 \\
\hline
\end{tabular}

$\mathrm{WE}=$ White Europians, $\mathrm{Ind}=$ Asians from the Indian sub-continent 


\section{Discussion}

The present study reveals that type II patterns (63.66\%) were the most common pattern of lip prints in both sexes. Tsuchihashi (17) however in his study mentioned that the commonest pattern was type III. Shivapathasundharam et al (17) and Vahanwala and Parekh (6) were of the opinion that it was type I, which was the most common pattern found in either sex. Hirarth (18) noted in his study that it was type II lip pattern which was most common in the upper lip and I' in the lower lip.

In the present study it was noticed that measurements of mouth width, height of upper and lower lips and the total lip height were slightly larger in males than in females. The findings are comparable with the results obtained by Wilkinson et al (19) on Asians from the Indian subcontinent of ethnic origin. Similar findings were obtained by the studies conducted by Farraio et al (20,21), Nanda et al (22), Farkas et al and Latta et al (23). The morphological types were noticed in the subjects. It was found that the medium type of the lips was most commonly present in all subjects. The order of frequency in males was medium $(40 \%)$, thick $(29.34 \%)$, thin $(24 \%)$ and puffy $(6.66 \%)$. The order of frequency in females was medium $(40 \%)$, thin $(36.67 \%)$, thick $(21.33 \%)$ and puffy (2\%). However, due to lack of literature comparison could not be made with the present study.

The study divulges that the lip prints of all the experimental subjects did not match with each other. This observation was similar to the observations noted by other workers namely Suzuki et al (10), Suzuki and Tsuchihashi (11), Suzuki and Tsuchihashi (12), Ebihara (13), Tsuchihashi (17), Kasprzak (3), William T (15) and Vahanwala and Parekh (16). No controversial statement in this respect has been observed by any other worker. Results advocated that positive identification can be done by studying lip print patterns as the lip print pattern is different in every individual.

The comparison could not be made due to lack of literature related to the long term study to advocate any changes in the dimensions of oral orifice a it is done in the present study until seven years.

\section{Conclusions}

The present study thereby concludes that the frequency of

a) the commonest pattern ( II )

b) least common pattern ( III )

c) Measurements of width of mouth, height of upper and lower lips and total lip height was greater in males as compared to females. It was concluded that males have a larger mouth and bigger lips than female.

d) Morphological types of lips: Medium types of lips were common in both sexes.

e) There was no change in anthropometric measurements after seven years study of a selected group of subjects

\section{REFERENCES}

[1] Lawrence H. Alimentary system. In: Williams P, Dyson M, Dussek JE, Bannister LH, Berry MM, Collins P, editors. Gray's Anatomy, $38^{\text {th }}$ ed. London: ELBS; 1995: 1687- 88.

[2] Bork K, Nikolas H, Gunter W. Diseases of the oral mucosa and the lips. $2^{\text {nd }}$ ed. Philadelphia: W.B. Saunders Co; 1996: 993.

[3] Kasprzak J. Possibilities of cheiloscopy. Forensic Sci Int 1990; 46: 145-51.

[4] Berkovitz BK. Textbook of Oral Anatomy. $1^{\text {st }}$ ed. Italy: Wolfe Publishing Ltd; 1992: 13.

[5] Leveque L, Goubanova E. Influence of age on the lips and perioral skin. Dermatology 2004; 208: 307- 13.

[6] Cottone JA, Standish SM. Textbook of Outline of Forensic Dentistry. USA: Year Book of Medical Publisher; 1982: 135.

[7] T.A. Trozzi, R.L. Schwartz, M.L. Hollars, Processing guide for developing latent prints, Forensic Sci. Commun. [online] (January) (2001).

[8] Suzuki K. Forensic odontology and criminal investigation. Acta Crim Japonica 1970; 36: 88- 102.

[9] Indera PS, Bhasin MK. A laboratory manual on biological anthropology. $1^{\text {st }}$ ed. Delhi: Kamla-Raj Enterprises, Nazia offset press; 1989: 71 .

[10] Suzuki K, Suzuki H, Tsuchihashi Y. On the female lips and rouge. Shikwa Gakuho 1967; 67: 471.

[11] Suzuki K, Tsuchihashi Y. New attempt of personal identification. J of Indian Dent Assoc 1970: 8- 9.

[12] Suzuki K, Tsuchihashi Y. Personal identification by means of lip prints. J of Forensic Medicine 1970; 17: 52- 57.

[13] Ebihara K. Personal communication by Tsuchihashi Y. 1971.

[14] Tsuchihashi Y. Studies on personal identification by means of lip prints. Forensic Sci 1974; 3: 233- 48.

[15] William TR. Lip prints-another means of identification. J of Forensic Indent 1991; 41: 192- 94.

[16] Vahanwala, Parekh B. Study of lip prints as an aid to forensic methodology. J of Forensic Medicine and Toxicology 2000; 17: $12-18$

[17] Shivapathasundharam B, Parkash A, Sivakumar G. Lip prints (Cheiloscopy). Indian J Dental Research 2001; 12: 234- 37.

[18] Hirth L, Gottsche H, Goedde HW. Lip prints- variability and genetics. Humangenetik 1975; 30: 47- 62.

[19] Wilkinson CM, Motwani M, Chiang E. The relationship between the soft tissues and the skeletal detail of the mouth. $\mathrm{J}$ Forensic Sci 2003; 48: 728- 32.

[20] Ferrario VF, Sforza C, Miani AJ, Tartaglia G. Craniofacial morphometry by photographic evaluations. Am J Orthod Dentofac Orthop 1993; 103: 327- 37.

[21] Ferrario VF, Sforza C, Serrao G. A three-dimensional 
quantitative analysis of lips in normal young adults. Cleft Plate Craniofacial J 2002; 37: 48- 54.

[22] Nanda RS, Ghosh J. Facial soft tissues harmony and growth in orthodontic treatment. Semin Orthod 1995; 1: 67- 81.

[23] Latta GH. The midline and its relation to anatomic landmarks in the patient. J Pros Dent 1988; 59: 681- 83. 